\title{
Getting into Print
}

\begin{abstract}
Editors of thirty-three national library periodicals were surveyed to identify the number of unsolicited manuscripts received and published annually. The review process to select manuscripts for publication was also examined. Our findings reveal a high manuscript rejection rate ( 77.3 percent) with little reliance on external judges to review potential articles. Journal editors are encouraged to publish the purpose and scope of their periodical, as well as the method and criteria used to review unsolicited manuscripts.
\end{abstract}

$\mathbf{R}$ AMPANT CRITICISM on the quality of library literature is so pervasive that we could be fearful that Katz's Best of 1978 might contain only one or two articles. This old question of quality has extensive roots, and it generated a renewed concern during the 1950s through the activities of the ALA Library Periodicals Round Table. At one meeting, Bell commented that reputable authors, "plus the maintenance of a standard of selectivity in articles printed, are the basic ingredients for attaining the much needed respect that a publication requires in order to flourish."1

A sustained and growing concern about quality is evident in articles selected from the past twenty years: "Dullness in Library Journals " (1953); ${ }^{2}$ "Standards for Library Periodicals" (1955); 3 "A Look at Library Literature" (1961); 4 "Popular or Scholarly" (1962); ${ }^{5}$ and "The Library Press" (1969). ${ }^{6}$ Moon makes a typical observation, "The dearth, the paucity of quality, is most noticeable if you examine only one element among the features of the library press: the articles."7 The topic has been important enough to merit attention at workshops and

Daniel O'Connor is assistant professor, Graduate School of Library Service, Rutgers University, New Brunswick, New Jersey, and Phyllis Van Orden is professor, School of Library Science, Florida State University, Tallahassee. This research was conducted while both authors were on the faculty at Rutgers University, and the authors acknowledge the support of the Graduate School of Library Service there and the assistance of Thomas H. Mott, Jr., Shirley Fitzgibbons, and Ruth Katz. conferences. Examples include a conference held at Brandeis University in $1975^{8}$ and a program of the Library Research Round Table held during the 1972 Annual Conference of ALA. ${ }^{9}$

These activities, however, address neither the question of the opportunity to publish nor the treatment that unsolicited manuscripts receive. If prospective authors are unaware of publication policies and criteria for selection, such ignorance may perpetuate the submission of manuscripts that will continue to generate criticism. Though "quality" is bandied about, it cannot come from situations where authors do not know criteria or where editors face copy deadlines with questionable manuscripts on hand. Sharing of criteria with prospective authors as well as with those involved in the reviewing process might serve as one concrete means of raising quality.

\section{FocUSING IN ON Two ASPECTS}

Because of these basic issues, selected national library journals were polled during fall 1976 to identify an author's chances of having an unsolicited manuscript published. An equally important aspect of the investigation was describing the way in which unsolicited manuscripts are presently reviewed to determine how articles are selected for publication.

Librarians publish, ideally, from their desire to communicate ideas with colleagues. There are growing pressures facing library school faculty and academic librarians to advance professionally through this activity.

Such individuals need to have available to 
them statements of the scope, policies, and criteria used by journals in selection of articles. The opportunities of individuals to share their research is also contingent upon the number of unsolicited manuscripts that can be accepted for publication each year. Besides knowing the appropriate journal for their manuscript, writers need to know the manuscript reviewing process and how much time this takes. These factors are of great significance to any potential author, especially one who is under pressure to establish publishing credit.

Thirty-three English language journals published in the United States and Canada were selected, as ones that accept contributions from members of the field, are indexed in Library Literature, and attract national audiences of librarians. Excluded were publications that are internal newsletters, agency or association publications that focus on regional or state activities, publications used as a vehicle for informal exchange of ideas, and national journals that consist solely of solicited articles.

Forty journals originally met our criteria for inclusion in the study. However, three journals were excluded after we realized that one changed its scope (to a newsletter), another ceased publication, and the third was only infrequently indexed in Library Literature. Two journals, Drexel Library Quarterly and Library Trends, consist solely of solicited articles. In addition, we were not able to reach two journal editors by either mail or telephone.

Based on these criteria, several excellent journals were excluded from the study. However, the importance of investigating practices in nationally based publications outweighed the advantages of a more thorough examination of all library periodicals. The journals selected vary widely in their subject matter and in the audiences that they attract; they range from subsidized association publications to commercial endeavors published by profit-making organizations.

\section{IDENTIFYING THE OPPORTUNITY TO PUBLISH}

The opportunity to publish depends on three basic considerations: (1) the author's interest in matching the subject and scope of a journal, (2) the approximate rate of ac- ceptance of unsolicited manuscripts, and (3) the ratio of unsolicited to solicited articles published by the journal. Another important factor is the total number of articles published annually.

The responses to these considerations are provided in table 1. As an example, the journal American Archivist reports receiving forty unsolicited manuscripts each year, of which 50 percent are accepted for publication. These accepted manuscripts represent approximately 75 percent of the total number of articles published in the journal each year.

The range of subjects dealt with by the journals in this study is diverse. Many journal titles suggest the key interests of their readers. Although an analysis by subject was outside the focus of this study, we did request copies of the information sent to prospective authors. Unfortunately, most of this information directs authors in matters of bibliographic format rather than identifying the scope of the journal. A noticeable exception is Information Processing and Management, which specifies its purpose, scope, typical key words, and related journals.

The overall findings of the opportunity to publish include:

1. An unsolicited manuscript stands about one chance in four of being published.

2. After an article is submitted, authors should anticipate a two-month delay before receiving an acceptance or rejection notification.

3. If the manuscript is accepted, an additional five months pass before the article is published.

4. The number of individuals who participate in the evaluation of a manuscript can vary from a single editor to a consensus from a group of individuals who review manuscripts without knowing the identity of the author. In fact, the most common pattern is that two to four readers will review a manuscript to determine if it is suitable for publication.

5. Unsolicited manuscripts account for more than two-thirds of the total articles published by the thirty-three journals identified in this study.

Nevertheless, manuscripts are not mailed to average journals. Instead, they are sent 
to a specific periodical, and its practices determine the opportunity of authors to see their ideas in print.

Table 1 identifies for each journal the number of unsolicited manuscripts received annually, their acceptance rate, and the percent of total articles generated from unsolicited manuscripts. It is common knowledge that many rejected manuscripts eventually appear as news items or as articles in other journals. ${ }^{10}$ The average acceptance rate for unsolicited manuscripts is $\mathbf{3 3 . 8}$ percent. This is a misleading figure given the extremes in the number of articles selected by different journals. For example, Argus reports a 100 percent acceptance rate, but only three manuscripts are involved. $\mathrm{Li}$ brary Journal, which receives 650 unsolicited manuscripts, reports an acceptance rate of 10 percent-or sixty-five articles. By computing the actual number of accepted manuscripts for all thirty-three journals, there was a total of 746 published articles from a pool of 3,292 unsolicited submissions, which represents an overall acceptance rate of 22.7 percent.

This unexpectedly high rejection rate of 77.3 percent surprised us when compared to the average rejection rates in other fields. In a review of the refereeing process, Meadows states that, "Only about a quarter of the papers submitted to U.S. science journals are rejected, though in some 'fringe' areas-such as mathematics and anthropology - the rejection rates rise to 50 percent. In arts subjects, on the other hand, over three-quarters of submitted articles may be refused."11

This raises the old question of where our field stands in relation to the disciplines. At the present time we obviously reflect the pattern of the arts. If we accept Meadows' analysis, then our more quantitative journals would be expected to have lower rejection rates than less quantitative ones.

This point is borne out in table 1 when looking at the acceptance rates of such journals as Bulletin of the Medical Library Association (50 percent), Information Processing and Management (60 percent), Journal of the American Society for Information Science (50 percent), and Special Libraries (49 percent). The reasons for this may not be obvious, unless one realizes that scien- tific journals often accept articles that contribute minor or esoteric advances in the field.

The implications of this raise a provocative question: Should librarians who publish for their own professional advancement in journals with high acceptance rates be required to produce more publications than those who publish in journals with low acceptance rates?

Another important consideration is the ratio of unsolicited to solicited manuscripts, which comprise the published articles in a library periodical volume. Column 4 of table 1 lists this publication rate for unsolicited manuscripts. These figures represent great variations in practice, and there are no discernible patterns to account for this in terms of subject area, manuscript reviewing process, or type of journal (i.e., association or commercial).

Questionnaire items relating to table 1 asked for the editor's best estimate; as such, publication rate is highly suspect. Ideally, the number of articles published annually by each journal could be obtained from table 1 by mutiplying column 2 times column 3 and then dividing the result by column 4. For some journals, this process yielded highly inaccurate numbers when compared to actual counts of articles published. We surmised that this was due to erroneous publication rate figures.

From actual counts and several estimates, the total number of articles published by these thirty-three journals during 1975 was 1,095. Of these, 746 , or 68.1 percent, came from unsolicited manuscripts, and the remaining 349 originated from solicited manuscripts. Thus it is safe to say that about two-thirds of the articles in our national journals come from unsolicited manuscripts. Given the severe rejection rate mentioned earlier, this publication rate constitutes an important commentary on the composition of our national journals: Both the editors of these publications and their respective audiences are dependent upon unsolicited manuscripts for communicating research among librarians.

Paradoxically, it is extremely difficult to have an unsolicited manuscript accepted for publication in a national library periodical, yet these journals are mostly comprised of 
TABLE 1

Opportunity to Publish Unsolicited Manuscripts

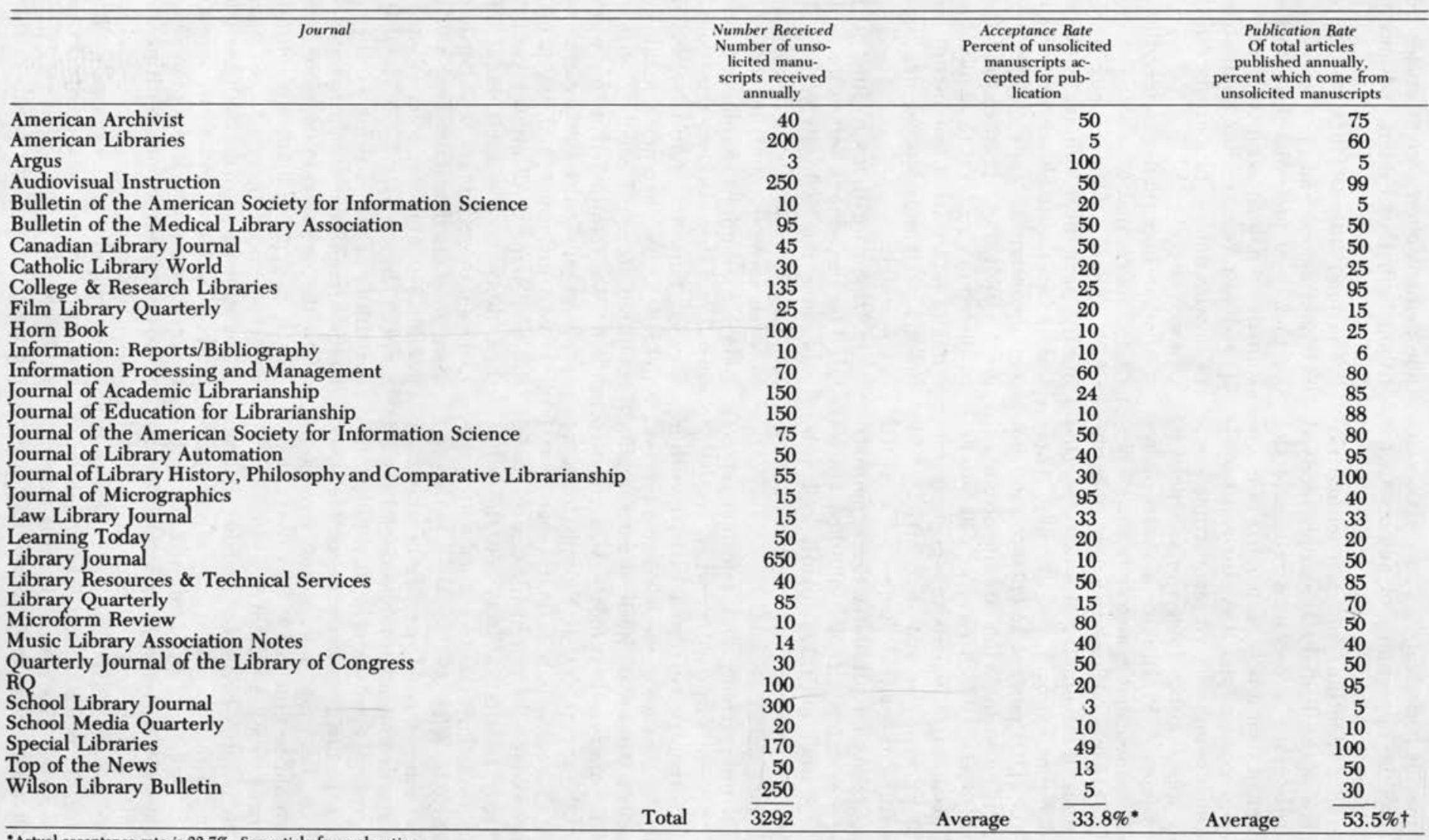


articles that originate from this source. Furthermore, editors still complain about the quality of manuscripts they receive. The following examination of the reviewing and refereeing process sheds some light on this dilemma.

\section{Revealing THE REVIEWING AND Refereeing Process}

A rejection rate of 77.3 percent provides evidence that the article selection process is a tough and vigorous one. Previous treatments of this topic tend to concentrate on the quality of manuscripts submitted to journal editors and not on the closely related editorial review and selection process. In these days of performance objectives, accountability, and evaluation, it seems only fair that editors identify for prospective authors the complex process by which unsolicited manuscripts are reviewed and selected. Confronted here are two fundamental issues: objectivity in reviewing manuscripts and the criteria used in selecting articles to be published.

The concept of objectivity in reviewing unsolicited manuscripts addresses the degree of a reviewer's impartiality in the selection process. Theoretically, objectivity in selecting manuscripts for publication exists on a continuum that can range from no evaluation (i.e., anything received is automatically published) to evaluation of a manuscript where an independent reviewer and a prospective author do not know each other's identity (frequently described as "double-blind refereeing").

From an a priori listing of nine discrete possibilities within this reviewing continuum, six emerged as patterns of practice in selecting manuscripts for publication. There were no journals that automatically publish anything received, and thus all manuscripts receive some degree of review. For most of the journals, this review is usually performed by members of an editorial or advisory board who know the identities of prospective authors.

Table 2 lists by journal the six reviewing practices used by nationally based library periodicals; also included are the number of individuals involved in unsolicited manuscript review as well as the time it takes to perform this activity. As a journal moves from high internal control by an editor to double-blind refereeing, there should be a corresponding increase in the objectivity with which manuscripts are selected for publication.

Although refereeing does not guarantee the production of quality manuscripts, it does inject independence and impartiality into the selection process. Ideally, a referee is an outside expert who judges anonymous manuscripts for their intrinsic worth; the referee also provides substantive suggestions to potential authors to help them improve the quality of their contributions. Though there appears to be movement toward refereeing, only six journals employed a full refereeing system, while the remaining twenty-seven periodicals relied primarily on editors, advisory staffs, and editorial boards to review and select manuscripts for publication.

(Several editors indicated that multiple reviewing practices were used. The assignment of a journal to a level in table 2 was based on the first category that an editor checked.)

For the ten level one journals, where the editor makes the selection, the sheer volume of this work is staggering: seventeen editors evaluate 784 unsolicited manuscripts annually, which amounts to an average of forty-six manuscripts per editor. This is in addition to preparing, coordinating, or evaluating features, editorials, theme issues, regular columns, and solicited manuscripts. Furthermore, many of the association publications have unpaid editors who perform these activities in addition to their regular jobs.

Refereeing is no immediate panacea that ensures the production of quality articles. For science journals, where this practice is widely used, the more prevalent negative aspects of refereeing include: time increases between receipt of manuscript and publication decision; use of different evaluation standards by different referees; difficulties in masking the identities of authors; and an occasional robbing of an author's idea by an unscrupulous referee. ${ }^{12}$ Nonetheless, the important consideration here is how these disadvantages of refereeing compare to the present systems of editorial control.

The major difference when adopting a 
TABLE 2

Level of Reviewing, Number of Individuals InVolved, and Time to Process Unsolicited Manuscripts

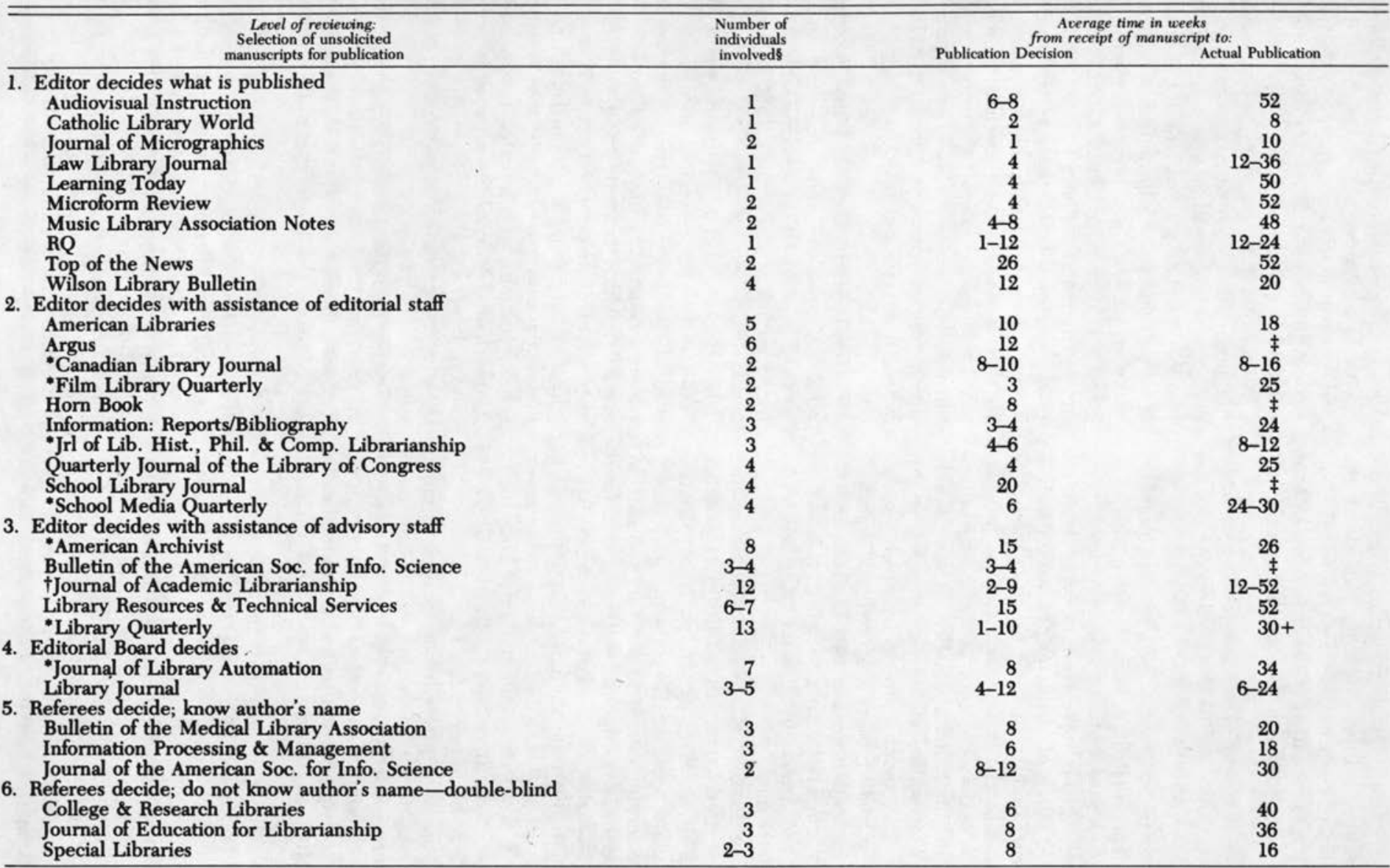

-Also uses outside referees who know author's name †Also uses double-blind refereeing system $\ddagger$ Did not respond

\$The questionnaire did not distinguish between number of individuals who serve as referees and the actual number involved in reviewing each manuscript. 
refereeing system would be the decisionmaking environment within our journals. Instead of a relatively small number of individuals making many decisions on wide ranges of topics, there would be many individuals each making a few decisions in their particular areas of expertise. The time delay between receipt of manuscript and publication decision now averages two months; with a refereeing system this is likely to increase. However, the average five-month time span from publication decision to actual publication should not be affected.

The most serious problems with refereeing are the criteria used to evaluate manuscripts and the consistency with which they are applied. Fortunately, several editors from levels 5 and 6 sent us the evaluation forms used by their referees, and these were most enlightening. The best conglomerate form would include specific evaluation criteria followed by a scale so manuscripts can be judged according to originality of ideas, importance to the journals' audience, clarity, appropriateness of method, and similar standards. ${ }^{13}$ In addition, an open-ended section for comments would allow referees to state specific criticisms of rejected manuscripts. Because this form is so important, editors should publish it regularly in their journals so prospective authors will know in advance the criteria used and how it is applied in the evaluation of their manuscript.

The other problems with refereeingmasking authors' identities and robbing of ideas-are rare but cannot be easily overcome. These merit close monitoring by journal editors.

Finally, it is our opinion that if journals lack a detailed purpose statement, do not provide for an objective review of manuscripts, and hide their evaluation criteria from prospective authors, then two things might happen: (1) There will be a high rejection rate for unsolicited manuscripts; and (2) there will be widespread complaints by editors that the quality of manuscripts received is very low.

\section{QUESTIONING THE QUESTION}

Previous writers on this topic have concentrated on vague notions of "quality" that should emanate from library periodicals.
This study does not pretend to address this issue in any direct manner. Instead, our investigation is a very specific one aimed at examining the method by which unsolicited manuscripts become published articles. An examination of thirty-three national journals, whose editors responded to a six-item questionnaire is, admittedly, a limited study. But we feel it is an important beginning in describing an influential segment of the library literature, whose combined circulation exceeds 335,000 subscriptions.

The treatment of unsolicited manuscripts reported here indicates a clear need to reassess the policies and levels of decision making within our national journals. We view a librarian's opportunity to publish as severely limited by the following factors: (1) high manuscript rejection rate; (2) lack of objectivity in the manuscript reviewing process; (3) uncertainty about the journal's purpose; and (4) ignorance of reviewers' evaluative criteria.

These issues deserve an open hearing to resolve the problems facing librarians who would like to communicate their ideas with colleagues. It is not enough to continue the current trend of workshops, where editors and researchers identify for librarians the ideal, publishable manuscript. Instead, journal staffs must reexamine and publicize their policies. This should also benefit the journals in providing them with external measures of stability when editors and editorial boards change.

Of course, we intend to end this on a positive, constructive note. A few journals have already accomplished some of the recommendations suggested in this study. The experiences of these editors should be shared with others to identify reasonable modifications of current practice as journals move toward the development of national guidelines.

The American Library Association can exercise leadership in this area by examining its periodicals to determine the pattern appropriate to each journal's purpose and audience. In addition, a conference of librarians and editors to discuss specific issues would go far in advancing the state of our journal literature.

To keep this in focus, we suggest that the initial considerations address three basic 
points: (1) Journals should regularly publish specific statements on their purpose, scope, and audience; (2) journals should publish the criteria used to evaluate manuscripts; and (3) journals should adopt a double-blind refereeing system.
These proposed changes should provide vehicles for the improvement of our literature to the benefit of editors, authors, and readers. Once these issues are resolved, we may look forward to Katz's Best of 1980 as a two-volume work.

\section{REFERENCES}

1. Ingelis Bell, "Mechanics of Editorial Work," ALA Library Periodicals Round Table Newsletter 6:5 (1959).

2. Jean Colquhoun, "Dullness in Library Journals," Ontario Library Review 37:86-87 (1953).

3. Leon Carnovsky, "Standards for Library Periodicals," Library Journal 80:264-69 (1955).

4. Fay M. Blake, "A Look at Library Literature," Wilson Library Bulletin 35:715, 720 (1961).

5. Eric Moon, "Popular or Scholarly?" Library Journal 87:2330 (1962).

6. Eric Moon, "The Library Press," Library Journal 94:4104-9 (1969).

7. Ibid., p.4105.

8. Jennie M. Harreld, "Report on the Conference on Writing and Publishing for Librar- ians," College of Research Libraries News 36:177-79 (June 1975).

9. "Is There a Need for a Journal of Library Research?" "Program of the 91st Annual Conference of the American Library Association, Chicago, Illinois, June 25-July 1, 1972," p.81.

10. Moon, "The Library Press," p.4105, and telephone conversation with John Berry, editor of Library Journal, on Oct. 25, 1976.

11. A. J. Meadows, Communication in Science (London: Butterworths, 1974), p.38.

12. Ibid., p.42.

13. A more thorough listing of criteria can be found in "American Libraries $\$ 1000$ Prize Article Competition," American Libraries 7:685 (1976). 


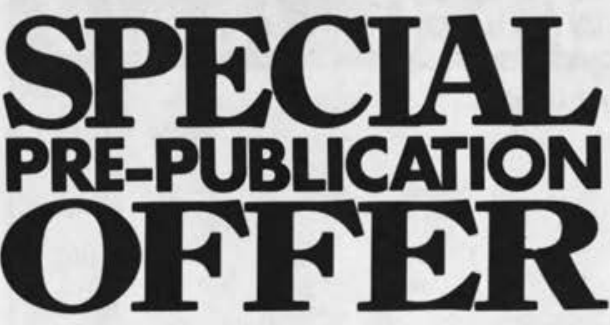

\section{ENCYCLOPEDIA OF BIOETHICS}

Editor in Chief: WARREN T. REICH, Center for

Bioethics, Kennedy Institute of Ethics, Georgetown University

A groundbreaking reference work - the only comprehensive source of information on social and ethical issues in the life sciences, medicine, health care, and the health professions. In over 300 cross-referenced articles ranging from Abortion to Zygote Banking, the major concepts, principles, and problems of bioethics-past and present- have been synthesized, analyzed, and compared. Distinguished international contributors explore significant ethical positions in all philosophical and religious traditions. The implications of these positions, the unresolved issues, and the anticipated developments are examined to encourage ethical reflection on the part of the reader. With an exhaustive index and an extensive bibliography following each article, the Encyclopedia of Bioethics is invaluable for researchers, students, educators, and professionals. Available in December 1978.

Four-volume set $\$ 200.00 \mathrm{~N}$ ISBN 0-02-926060-4 Special Pre-publication Price: $\$ 180.00$

Order before December and save $10 \%$.

\section{INTERNATIONAL ENCYCLO- PEDIA OF STATISTICS}

Edited by WILLIAM H. KRUSKAL, University of Chicago, and JUDITH M. TANUR, State University of New York at Stony Brook

The most extensive, definitive reference work on statistics in print, covering the development of modern statistical methods and describing the operations, interpretations, and applications of various statistical techniques. This two-volume set (1344 pages) is fully cross-referenced, alphabetically arranged, and includes: 75 articles on statistics proper, 42 articles on social science topics with special relevance to statistics, 57 biographies, extensive bibliographies following each article, complete index. An essential reference tool for statisticians, social scientists, engineers, medical researchers, market researchers, and anyone who uses or has to understand statistics. Available in November 1978.

Two-volume set $\$ 100.00 \mathrm{~N}$

Special Pre-publication Price: $\$ 90.00$

ISBN 0-02-917960-2 Order before November and save $10 \%$.

\section{BAKER'S BIOGRAPHICAL DICTIONARY OF MUSICIANS}

\section{Sixth Edition}

NICHOLAS SIONIMSKY

At last, the long-awaited new edition of Baker's -the classic one-volume reference work of musical biography for over 75 years. More than one thousand entries have been added and thousands more have been completely revised, making the Sixth Edition more comprehensive, authoritative, and up-to-date than any previous editions. Baker's offers immediate access to the most pertinent information on virtually all the well-known and little-known figures in the music world: composers, singers, instrumental virtuosos, orchestral conductors, critics, librettists, publishers, impresarios, instrument makers, scholars and patrons of music. The approximately 12,000 musical portraits span the history of music from the Middle Ages to the age of rock and include lists of works and selective bibliographies. Musicians, music scholars, and music lovers will find Baker's a must-an engaging and enlightening guide to the people who make music.

Available in December 1978.

One volume, 2000 pages $\quad \$ 75.00 \mathrm{~N}$

ISBN 0.02-870240-9

Special Pre-publication Price: $\$ 65.00$

\section{Order from:}

\section{MACMILLAN PROFESSIONAL AND} LIBRARY SERVICES

A Division of Macmillan Publishing Co., Inc. 100B Brown Street, Riverside, New Jersey 08370 


\section{REPRINTS RELEASE}

Barclay

Bendat

Bernstein

Berwanger

Billingsley

Bloom

Bodnar

Bowsky

Broudy

Broudy et al

Bullough

Butler

Cater/Lee

Chalmers

Chikazumi/Charap

Chua

Cohn

Connelly

Dean et al

Dean

Denn

Disque

Easton

Eringen

Filler

GelFand

Gilbert

Glorig

Grazda et al

Grinspoon et al

Hecht et at

Himwich

Jackson/Messick

Javid/Brenner

Jones

Keys

Kneller

Mamatey

Miller

Morrison

Oidenberg/Holladay Oison

TITLE

FOUNDATIONS OF COUNSELING STRATEGIES

PRINCIPLES AND APPLICATIONS OF RANDOM NOISE THEORY

AUD1O SYSTEMS

AS THEY SAW SLAVERY

ERGODIC THEORY AND INFORMATION

GAS LASERS

STRUCTURAL ADHESIVES BONDING

THE BLACK DEATH

78 and 79

BUIL OING A PHIL OSOPHY OF EDUCATION

DEMOCRACY AND EXCELLENCE IN AMERICAN SECONDARY EDUCATION 1964

THE SCIENTIFIC REVOLUTION

CORROSION AND ITS PREVENTION IN WATERS

POLITICS OF HEALTH

PRINCIPLES OF SOLIDIFICATION

PHYSICS OF MAGNETISM

INTROOUCTION TO NON LINEAR NETWORK THEORY

(Subdivided into 3 parts)

DIFFEAENCE ALGEBRA

THE EPOCH OF NAPOLEON

MATHEMATICS FOR MODERN MANAGEMENT

OPERATIONS RESEARCH IN RESEARCH DEVEL OPMENT

OPTIMIZATION BY VARIATIONAL. METHOOS

APPLIED PLASTIC DESIGN IN STEEL

A SYSTEMS ANALYSIS OF POUTICAL LIFE

MECHANICS OF CONTINUA

FROM POPULISM TO PROGRESSIVISM. Representative Selections

(formerly titled: Late 19th Century American Liberalism)

IECTURES ON UINEAR ALGEBRA

SULFONATION AND RELATEO REACTIONS

AUDIOMETRY Principles and Practices

HANDBOOK OF APPLIED MATHEMATICS

SCHIZOPHRENIA: Pharmacotherapy and Psychotherapy

THE WOMEN. YES

BIOCHEMISTRY SCHIZOPHRENIAS AND AFFECTIVE ILLNESSES

PAOBLEMS IN HUMAN ASSESSMENT

ANALYSIS TRANSMISSION AND FILTERING OF SIGNALS -

THE FORMATION OF THE CONSTITUTION

THE HISTORY OF SURGICAL ANESTHESIA

EDUCATIONAL ANTHROPOLOGY: An Introduction

RISE OF THE HASBURG EMPIRE $1526-1815$

THE INVESTITURE CONTROVERSY

INTRODUCTION TO ATOMIC AND NUCLEAR PHYSICS

MODERN SOUND REPRODUCTION

ORGANIC PEACTIONS-Volumes 1,14,15 (complete set available)

Parrish

Pope/Harper

Rall

Rose

Ross

Saloutos

Schwartz

Slattery

Seymout

Strahler

Thaler

Waddell

Willis

Wymore

THE CIVIL WAR

HIGH-SPEED WINO TUNNEL. TESTING

COMPUTATIONAL SOLUTION OF NONLINEAR OPERATOR EOUATIONS 1960

CONCEPTS IN PHOTOCONOUCTIVITY AND ALLED PROBLEMS 1963

THE FRENCH REVOLUTION

POPULISM Reaction or Reform?

SURFACE ACTIVE AGENTS AND DETERGENTS - Vol 1

MOMENTUM. ENERGY. AND MASS IRANSFER IN CONTINUA

INTRODUCTION TO POLYMER CHEMISTRY

INTROOUCTION TO ENVIRONMENTAL SCIENCE

ELECTRIC MACHINES: Dynamics and Steady State

PRACTICAL QUALITY CONTROL FOR CONCREIE

DeGAULLE Anachronism. Realist. or Prophet?

A MATHEMATICAL. THEORY OF SYSTEMS ENGINEERING The Elements 1967

PAGES PRICE

$470 \mathrm{pp} \quad \$ 1575$

$456 \mathrm{pp} . \quad \$ 1850$

$424 \mathrm{pp}$ in Prep

$176 \mathrm{pD}$. ppb $\$ 750$

$210 \mathrm{pP} \quad$ In Prep

$184 \mathrm{pp} . \quad \$ 1350$

504 pp. In Prep.

$134 \mathrm{pp} \quad \mathrm{ppb} \$ 450$

$\triangle 26 \mathrm{pD} \quad \$ 16.50$

$310 \mathrm{pP} . \quad \$ 1200$

$136 \mathrm{PP} \quad \mathrm{DPb} \$ 450$

$312 \mathrm{pp} \quad$ In Prep

$248 \mathrm{pp}$. In Prep

$336 \mathrm{po} \quad \$ 1695$

$554 \mathrm{pp} \quad$ In Prep.

In Prep.

$\$ 1950$

ppb $\$ 450$

$\$ 1650$

$\$ 12.95$

$\$ 22.50$

$\$ 15.50$

$\$ 1750$

In Prep.

In Prep.

$\$ 1150$

$\$ 2250$

$\$ 1450$

52050

$\$ 1575$

In Prep

$\$ 2450$

$\$ 32.50$

$\$ 17.50$

ppb. $\$ 4.50$

$\$ 950$

$\$ 850$

ppb. $\$ 4.50$

In Prep.

pob $\$ 450$

$\$ 1750$

In Prep

$\$ 1950$ each

ppb. $\$ 4.50$

In Prep.

In Prep.

In Prep.

ppo $\$ 450$

ppb. $\$ 450$

In Prep.

In Prep.

In Prep.

$\$ 1850$

$\$ 2500$

$\$ 19.50$

ppb $\$ 450$

$\$ 19.50$

REPRINTS WITH CORRECTIONS OR UPDATING

$\begin{array}{lllll}\text { Norton } & \text { FINE CERAMICS } & 1970 & 524 \mathrm{pp} . & \text { In Prep. } \\ \text { Perrin } & \text { ORGANIC COMPLEXING REAGENTS } & 1964 & 378 \mathrm{pp} . & \text { in Prep } \\ \text { Plann } & \text { ZONE MELING } & 1958 & 326 \mathrm{pp} & \$ 15.75 \\ \text { Ralston } & \text { INTRODUCTION TO PROGRAMMING AND COMPUTER SCIENCE } & 1971 & 538 \mathrm{pp} & \text { in Prep. } \\ \text { Stipe } & \text { THE DEYELOPMENT OF PHYSICAL THEORIES } & 1967 & 494 \mathrm{pp} & \text { In Prep }\end{array}$

Stipe

THE DEVELOPMENT OF PHYSICAL. THEORIES

In Prep. 


\section{REPRINTS RELEASED in 78 in 79}

Brems
Brown
Bube
Bykhovsky
Chang
Chapple/Coon
Chapple
Condoyannis
Condoyannis
Fararo
Gregory

Hackett/Williamson Harnwell/Livingood Hart

Heald

Herzberger

Howell

Johnson

Johnson

Lewis

Lindmayer /Wrigley

McCarthy

Morgan

Morrish

Mysels

\section{REPRINTS WITH CORRECTIONS OR UPDATING}

QUANTITATIVE ECONOMIC THEORY: A Synthesis Approach

MICROMAGNETICS

PHOTOCONDUCTIVITY OF SOLIDS

FUNDAMENTALS OF VIBRATION ENGINEERING

BASIC PRINCIPLES OF SPECTROSCOPY

PAINCIPLES OF ANTHROPOLOGY

REHABILITATION THE DYNAMIC OF CHANGE

SCIENTIFIC GERMAN

SCIENTIFIC RUSSIAN

MATHEMATICAL SOCIOLOGY

A COLLECTION OF MATRICES FOR TESTING COMPUTATIONAL ALGORITHMS

ANATOMY OF READING

EXPERIMENTAL ATOMIC PHYSICS

COMPUTER APPROXIMATIONS

PLASMA DIAGNOSTICS WITH MICROWAVES

MODERN GEOMETRICAL OPTICS

INTRODUCTION TO GEOPHYSICS

$968 \quad 532 \mathrm{pP}$

1963

$154 \mathrm{pp}$

482 pD

360 pp

$314 \mathrm{pp}$

$730 \mathrm{pp}$.

$122 \mathrm{pp}$.

$174 \mathrm{pp}$.

$238 \mathrm{pp}$

830 pp.

$164 \mathrm{pp}$

$272 \mathrm{PD}$.

$486 \mathrm{pp}$

$356 \varnothing p$.

$470 \mathrm{pp}$.

$416 \mathrm{pp}$

$412 \mathrm{pP}$

$360 \mathrm{pp}$.

$160 \mathrm{pp}$

$544 p p$

$496 \mathrm{pp}$

$416 p p$

$526 \mathrm{pp}$.

$489 \mathrm{pp}$.

$696 \mathrm{pp}$.

492 op

In Prep

in Prep

In Prep

in Prep

In Prep

In Prep

In Prep

in Prep

In Prep

in Prep

$\$ 1500$

$\$ 9.95$

in Prep

In Prep

In Prep

in Prep

In Prep.

$\$ 17.50$

$\$ 1250$

In Prep.

In Prep

In Prep.

In Prep

in Prep

in Prep

in Prep.

ADVANCE INFORMATION ON 1978/79 TITLES [NEW]

\begin{tabular}{|c|c|c|c|c|}
\hline AUTHOR & TIILE & $\begin{array}{l}\text { ORIG. } \\
\text { EQ. }\end{array}$ & PAGES & PAICE \\
\hline Anderson & •PUBUC POLICY MAKING & 1978 & $160 \mathrm{pD}$. approx. & $\mathbf{5 1 0} 50$ \\
\hline Armstrong & "IDEOLOGY, POUTICS \& GOVERNMENT IN SOVIET UNION & 1978 & $256 \mathrm{pp}$ & $\$ 9.95$ \\
\hline Banerii & ENERGY ECONOMY IN DESIGN & 1978 & & In Prep. \\
\hline Boschmann/Welcher & ORGANIC REAGENIS FOR COPPER & 1978 & $550 \mathrm{pp}$. approx. & In Prep. \\
\hline Graupe & $\begin{array}{l}\text { THE RISE OF MODERN JUDAISM- } \\
\text { An Intellectual History of German Jewry 1650-1942 }\end{array}$ & 1978 & $394 \mathrm{pp}$. & $\$ 1950$ \\
\hline Hinton & 'INTRODUCTION TO CHINESE POUTICS & 1978 & $336 \mathrm{pp}$ & $\$ 1195$ \\
\hline liams & PEACEMAKING FROM VERGENNES TO NAPOLEON & 1979 & 140 pp. approx. & In Prep. \\
\hline Lang & $\begin{array}{l}\text { ABSORPIION SPECTRA IN THE ULTRAVIOLET \& VISIBLE } \\
\text { REGION-VOL } 22\end{array}$ & 1978 & 198 pp. & $\$ 4250$ \\
\hline Mappen & WITCHES AND HISTORIANS: Interpretations of Salem Witchcraft & 1979 & 260 pp. approx. & In Prep. \\
\hline Martin/Stubaus & AMERICAN REVOLUTION: WHOSE REVOLUTION? & 197 & $168 \mathrm{pp}$ & ppb. .54 .50 \\
\hline Meyer & -THE POLITICAL EXPERIENCE & 1978 & $224 \mathrm{pp}$ & $\$ 10.95$ \\
\hline Morgan & THE PHYSICAL BASIS OF MUSICAL SOUND & 1979 & $200 \mathrm{pp}$. approx. & In Prep. \\
\hline Poole & $\begin{array}{l}\text { BEHIND THE IMPERIAL PRESIDENCY } \\
\text { Six Men Who Shaped U.S. Foreign Policy } 1941-1976\end{array}$ & 1979 & 120 pp. approx. & In Prep. \\
\hline Preston/Wise & -MEN IN ARMS & 1978 & $424 \mathrm{pp}$ & In Prep \\
\hline $\begin{array}{l}\text { Roback et al } \\
\text { Rooney }\end{array}$ & $\begin{array}{l}\text { GROUP PSYCHOTHERAPY RESEARCH. Commentaries and Readings } \\
\text { LAMENESS: A Horse Owner's Guide }\end{array}$ & $\begin{array}{l}1978 \\
1979\end{array}$ & 320 pp. approx & $\begin{array}{l}\text { In Prep. } \\
\text { In Prep. }\end{array}$ \\
\hline Snead & WORLD ATLAS OF GEOMORPHIC FEATURES & 1978 & 320 pp approx & \\
\hline Spanier & •HOW AMERICAN FOREIGN POLICY IS MADE & 1978 & & \\
\hline Stollak & UNTIL WE ARE SIX & 1978 & $132 \mathrm{pD}$ approx & \\
\hline
\end{tabular}

-Joint publication with Holt. Pinehart s

\section{REVISED EDITIONS}

\begin{tabular}{|c|c|c|c|c|}
\hline Chattield & A HISTORY OF ACCOUNTING THOUGHT & 1974 & $322 \mathrm{pp}$ & $\begin{array}{r}\text { c. } \$ 1650 \\
\text { ppb. } \$ 9.50\end{array}$ \\
\hline Chiang & INTRODUCTION TO STOCHASTIC PROCESSES \& THEIR APPLICATIONS & 1968 & 313 pp. approx. & In Prep. \\
\hline Enrick & INDUSTRIAL ENGINEERING MANUAL & 1962 & $270 \mathrm{pp}$ & In Prep. \\
\hline Firmage & FUNDAMENTAL THEORY OF STRUCTURES & 1963 & $350 \mathrm{pp}$ approx. & $\$ 1450$ \\
\hline Hughes & OIL. PROPEATY VALUATION & 1967 & $324 \mathrm{pp}$ & In Prep. \\
\hline Lowenthal & PHARMACEUTICAL CALCULATIONS-A Selt-Instructional Text & 1969 & $424 \mathrm{pp}$ & $\$ 11.50$ \\
\hline Luthin & DRAINAGE ENGINEERING & 1966 & 258 pp. approx. & $\$ 16.50$ \\
\hline Malloy/Turnet & ECONOMIC THICKNESS OF THERMAL INSULATION & 1961 & & In Prep \\
\hline Malloy & THERMAL INSLUATION & 1969 & $570 \mathrm{pD}$ & In Prep. \\
\hline Poole & EIGHT PRESIDENTS AND INDOCHINA & 1973 & $160 \mathrm{pp}$. approx. & ppb S525 \\
\hline
\end{tabular}

\section{ROBERT E. KRIEGER PUBLISHING CO. INC. P.O. BOX 542 HUNTINGTON, N.Y. 11743 USA}




\section{GENERAL SCIENCE INIDEX}

General Science Index is a new index specifically designed to help make access to and research with science periodicals more effective for public library patrons and students of all ages. Now, non-specialists may investigate, with greater ease, a wide variety of scientific topics and studies. Covering all the major areas in science today, General Science Index offers indexing for 89 English language periodicals that encompass both numerous and/ or individual subject fields.

Carefully selected periodicals in the following areas are indexed:

\section{Astronomy \\ Atmospheric Sciences \\ Biological Sciences \\ Botany \\ Chemistry \\ Earth Sciences \\ Environment and Conservation \\ Food and Nutrition \\ Genetics}

From questions concerning astronomy to those about zoology, General Science Index provides users with a useful guide to recently published material. Using a subject entry format for all articles, indexing is conducted by experienced librarians with subject specialties. A special subject authority file was established at the inception of the Index to assure continuity and consistency of the headings, and a complete system of cross-references has been

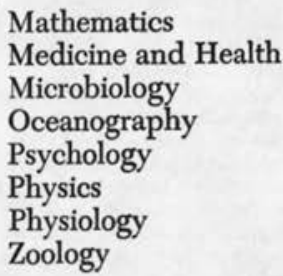

Mathematics

Medicine and Health

Microbiology

Oceanography

Psychology

Physics

Physiology

Zoology

employed with each issue. Whenever possible, a commonly used name or familiar contemporary term is used with a see reference from the traditional, often Latin, or scientific term, thus giving access to many articles through either name. Another valuable source of information in the Index is the separate section devoted to citations of book reviews, a feature that appears in each issue.

\section{The $N E W$ Index to Scientific Literature}

General Science Index, which began publication in July of 1978, is issued monthly, except in June and December. Cumulative issues appear in September, November, February, and May. An annual permanent hardbound cumulation is included in the subscription price. General Science Index is sold on the service basis. For a quotation of your service basis rate, please write for the General Science Index list of periodicals indexed. Check the periodicals your library now receives or expects to receive during the coming year. Requesting your service basis rate does not, of course, obligate you to subscribe.

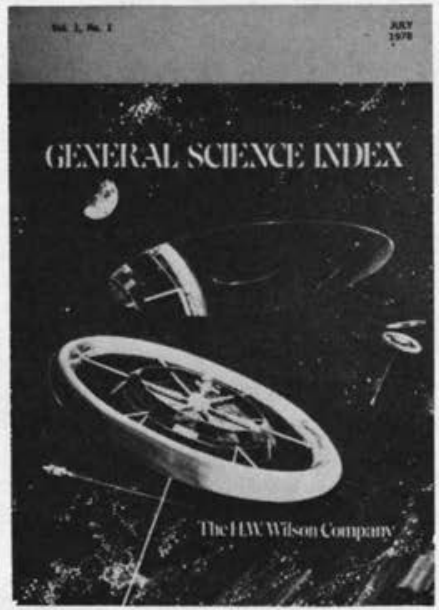

\section{THE H. W. WILSON GOMPANY}

950 University Avenue, Bronx, New York 10452 